\title{
Mesanenin Sarkomatoid Karsinom Varyant Histolojisi: Olgu Serisi ve Literatür Değerlendirmesi
}

\author{
Sarcomatoid Carcinoma, a Variant Histology of the Bladder: Case Series and Literature Review
}

\author{
Yavuz Onur Danacıoğlu', Rabia Burçin Girgin², Ferhat Keser', Asıf Yıldırım' \\ 1 İstanbul Medeniyet Üniversitesi, Göztepe Eğitim ve Araștırma Hastanesi, Üroloji Kliniği \\ 2 İstanbul Medeniyet Üniversitesi, Göztepe Eğitim ve Araștırma Hastanesi, Patoloji Kliniği
}

Geliș tarihi (Submitted): 08.02.2019

Kabul tarihi (Accepted): 12.07.2019

Yazıșma / Correspondence Op. Dr. Yavuz Onur Danacioğlu ORCID: 0000-0002-3170-062X Bakırköy Dr. Sadi Konuk Eğitim ve Araştırma Hastanesi, Üroloji Kliniği İstanbul, Türkiye

E-mail: dr_yonur@hotmail.com Tel: +905322935673

\section{(1) (8)}

Bu eser Creative Commons AtıfGayriTicari 4.0 Uluslararası Lisansı ile lisanslanmıștır.

\section{Özet}

Amaç: Agresif seyirli olan sarkomatoid ürotelyal karsinomlar, diğer ürotelyal kanser tiplerine göre daha kötü prognoza, daha ileri evreye ve daha fazla oranda metastaz riskine sahiptirler. Bu çalışmada mesanenin sarkomatoid ürotelyal karsinomu tanısı alan 10 hastanın klinik ve histopatolojik sonuçları literatür eşliğinde sunulacaktır.

Gereç ve Yöntemler: Çalışmaya Kasım 2012 ve Aralık 2018 tarihleri arasında histopatolojik olarak sarkomatoid karsinom tanısı alan 10 hasta dahil edildi. Hastaların demografik özellikleri ve patoloji sonuçları retrospektif olarak değerlendirildi. Hastalar ameliyat öncesi ayrıntılı öykü, fiziksel inceleme, rutin biyokimyasal ve hematolojik tetkikler, üriner ultrasonografi, abdominopelvik tomografi, akciğer grafileri ve sistoskopi ile değerlendirildiler.

Bulgular: Hastaların ortalama yaşı ve ortalama takip süreleri sırası ile 70,2 (51-81) y1l ve 9,2 (2-18) ay olarak saptandı. Hastaların başvuru şikayetlerinin makroskopik hematüri olduğu gözlendi. Altı (\%60) hastaya radikal sistektomi ameliyatı uyguland. Bir hasta neoadjuvan kemoterapi aldı. Radikal sistektomi sonrasinda $1(\% 16,6)$ hastada evre pT2b tümör, 3 (\%50) hastada evre pT3 tümör ve 2 $(\% 33,3)$ hastada evre pT4 tümörün olduğu görüldü. Üç (\%50) hastanın N1 olduğu görül-

\section{Abstract}

Objective: Sarcomatoid urothelial carcinoma has an aggressive nature; a worse prognosis, a more advanced stage and a greater risk of metastasis than other types of urothelial cancers. In this study, the clinical and histopathological results of 10 patients with sarcomatoid urothelial carcinoma of the bladder will be presented and the current literature will be reviewed.

Material and Methods: The study included 10 patients histopathologically diagnosed as sarcomatoid carcinoma between November 2012 and December 2018. Demographic characteristics and pathology results were evaluated retrospectively. Patients were evaluated with detailed history, physical examination, routine biochemical and hematological examination, urinary ultrasonography, abdominopelvic tomography, chest radiography and cystoscopy before surgery.

Results: The mean age and mean followup period of the patients were 70.2 (51-81) years and 9.2 (2-18) months respectively. The mean symptom of the patients was macroscopic hematuria. Six (60\%) patients underwent radical cystectomy. One patient received neoadjuvant chemotherapy. One (16.6\%) patient had a stage of pT2b tumor, three (50\%) patients had a stage of pT3 tumor and two (33.3\%) patients had a stage of pT4 tumor after radical 
dü ve üç (\%50) hastada eşlik eden CIS varlığı saptandı. Lenf nodu tutulumu açısından 3 (\%50) hastada metastaz mevcuttu. Yapılan takiplerde 6 (\%60) hastada hastalığa bağlı ölüm görülürken, 4 (\%40) hasta halen takip edilmektedir.

Sonuç: Mesanenin sarkomatoid karsinomları genelde agresif seyretmekte ve hastalar ileri evre tümörle tarafımıza başvurmaktadırlar. Radikal cerrahi tedaviye karşın bu tür tümörlerin erken nüks ve progresyon göstereceği göz önünde bulundurularak bu hastaların yakın takip edilmeleri gerekmektedir.

Anahtar Kelimeler: Mesane tümörü, sarkomatoid karsinom, varyant histoloji cystectomy. Three (50\%) patients were found to have N1 disease and three (50\%) patients had coexisting carcinoma in situ (CIS). Metastasis for lymph node involvement was present in three (50\%) of the patients. Six $(60 \%)$ patients have died due to disease, four (40\%) patients are still continued to follow up.

Conclusion: Sarcomatoid carcinoma of the bladder is usually an aggressive tumor and patients are referred with advanced stages. Despite radical surgery, these patients should be followed up closely as early recurrence and progression can be seen.

Keywords: Bladder cancer, sarcomatoid carcinoma, variant histology

\section{Gíiş}

Mesane kanseri dünya çapında en sık gözlenen 9. kanserdir ve prostat kanserinden sonra en sik gözlenen genitoüriner kanserdir (1). Mesanenin ürotelyal kanserleri farklılaşma eğilimi gösterebilmektedirler. Çeşitli farklılıklar tespit edilse de histopatolojik incelemelerde yaklaşı \%90 pür transizyonel hücreli (ürotelyal) karsinom, \% 10 diğer varyant histolojiler saptanmaktadır (2). Nadir olarak rastlanan ve kötü prognoza sahip olan varyant histolojiler arasında squamöz, glandüler, mikropapiller, nested, lenfoepitelyoma benzeri, plazmositoid ve sarkomatoid tip yer almaktadır ve günümüzde bunların sinıflandırılması amacıyla yapılan DSÖ (dünya sağlık örgütü)'nün 2004 sinıflaması kullanılmaktadır (3). Rutin hemotoksilen-eozin (H\&E) değerlendirmenin yanısıra yapılan çeşitli biyolojik değerlendirmeler sonucu sınıflandırılan ve varyant histolojilerden biri olan sarkomatoid karsinomun prevelansı \% 0,3-0,6'dır (4). Ürotelyal karsinom gibi sarkomatoid karsinom da ileri yaş hastalarda görülmektedir. Wang ve ark yaptığı çalışmada tanı yaşının 75 (41-96) yıl olduğu belirlenmiş ayrıca bu çalışmada erkek kadın oranının 1,9:1 olduğu tespit edilmiştir (5). Non-epitelyal tümör olan karsinomatöz ve sarkomatöz komponentlerin her ikisini de kendi içinde barındıran bu nedenle sarkomatoid karsinom terimi kullanilan bu histopatolojik tanım literatürde küçük vaka serileri veya anektodal tecrübeler şeklinde bildirilmektedir (6). Varyant histolojiye sahip mesane kanserleri daha agresif bir seyir gösterebilmekte ve çeşitli prognostik özelliklere sahip olabilmektedirler. Bu özelliklerinden ötürü mesanenin sarkomatoid karsinom (MSK) tanısı alan hastaların klinik seyri ve tedavi yaklaşımları saf ürotelyal karsinoma göre farklılık göstermektedir. $\mathrm{Bu}$ çalışmada; kliniğimizde MSK tanısı alan ve tedavisi yapılan hastaların klinik ve histopatolojik sonuçları sunularak güncel literatür eşliğinde değerlendirilmesi amaçlanmıştır.

\section{GEREÇ VE YÖNTEMLER}

Çalışmaya Kasım 2012 ve Aralık 2018 tarihleri arasında mesane kanseri ön tanısı ile transüretral mesane tümörü rezeksiyonu (TUR-MT) veya radikal sistektomi ve bilateral genişletilmiş lenfadenektomi ameliyatı yapılan 490 hasta içinden histopatolojik olarak MSK tanısı konulan $10(\% 2,04)$ hastanın klinik ve histopatolojik özellikleri retrospektif olarak değerlendirildi. Hastalar ameliyat öncesi ayrıntılı öykü, fiziksel inceleme, rutin hematolojik ve biyokimyasal tetkikler, tam idrar tetkiki, üriner ultrasonografi (USG), toraks ve abdominopelvik bilgisayarlı tomografi (BT) veya manyetik rezonans (MRI) görüntüleme ve sistoskopi ile değerlendirildiler. Histopatolojik ve immunohistokimyasal değerlendirme deneyimli üropatolog tarafindan yapıldı (Tablo 2). Klinik ve patolojik evreleme 2002 yılında kabul edilen TNM (tümör, lenf nodu, metastaz) sistemine göre yapıldı. Epitelyal ve sarkomatoid komponentler açısından histolojik değerlendirme DSÖ’nün güncel mesane kanseri sinıflama sistemine göre yapıldı. Ameliyat sonrası takiplerinde hastalar klinik ve fiziksel inceleme, rutin hematolojik ve biyokimyasal tetkikler, akciğer grafileri ve abdominopelvik BT veya MRI ile değerlendirilirken gerektiğinde tüm vücut kemik sintigrafisi, toraks ve kraniyal BT yapıldı. 
Tablo 1: Hastaların klinik ve onkolojik özellikleri

\begin{tabular}{|c|c|c|c|c|c|c|c|c|c|c|c|}
\hline Olgu & $\begin{array}{l}\text { Yaş } \\
(\mathrm{y} 1 \mathrm{l})\end{array}$ & $\begin{array}{l}\text { Cinsiyet } \\
(\mathrm{E} / \mathrm{K})\end{array}$ & VKİ & Şikayet & $\begin{array}{l}\text { Sigara } \\
(\mathrm{pk} / \mathrm{yl})\end{array}$ & $\begin{array}{c}\text { Operasyon } \\
\text { Türü }\end{array}$ & $\begin{array}{c}\text { İntravezikal } \\
\text { Tedavi }\end{array}$ & $\begin{array}{l}\text { Neoadjuvan } \\
\text { KT Öyküsü }\end{array}$ & $\begin{array}{c}\text { Adjuvan } \\
\text { KT } \\
\text { Öyküsü }\end{array}$ & $\begin{array}{c}\text { Takip } \\
\text { Süresi } \\
\text { (ay) }\end{array}$ & Durum \\
\hline I & 69 & $\mathrm{E}$ & 25,9 & Hematüri & 32 & Sistektomi & Yok & Yok & Yok & 4 & Exitus \\
\hline II & 81 & $\mathrm{E}$ & 23,8 & Hematüri & 81 & TUR-M & BCG & Var & Var & 11 & Exitus \\
\hline III & 51 & E & 23,4 & Hematüri & 25 & Sistektomi & Yok & Yok & Yok & 2 & Exitus \\
\hline IV & 81 & $\mathrm{E}$ & 20,7 & Hematüri & 60 & TUR-M & Yok & Yok & Yok & 6 & Exitus \\
\hline $\mathrm{V}$ & 73 & $\mathrm{E}$ & 20,3 & Hematüri & 100 & Sistektomi & Yok & Yok & Yok & 9 & Exitus \\
\hline VI & 66 & E & 28,3 & Hematüri & 25 & Sistektomi & Yok & Yok & Var & 18 & Yaşıyor \\
\hline VII & 71 & $\mathrm{~K}$ & 26,7 & Hematüri & 0 & Sistektomi & Yok & Yok & Yok & 14 & Yaşıyor \\
\hline VIII & 72 & $\mathrm{~K}$ & 27,5 & Hematüri & 0 & Sistektomi & Yok & Yok & Yok & 6 & Exitus \\
\hline IX & 71 & $\mathrm{E}$ & 34,8 & Hematüri & 52 & TUR-M & Yok & Yok & Yok & 13 & Yaşıyor \\
\hline $\mathrm{X}$ & 67 & $\mathrm{E}$ & 29,3 & Hematüri & 60 & TUR-M & BCG & Yok & Yok & 9 & Yaşıyor \\
\hline
\end{tabular}

VKİ: Vücut kitle indeksi TUR-M: Transüretral mesane tümörü rezeksiyonu KT: Kemoterapi pk/yll: paket/yll BCG: Bacillus calmette guerin

\section{BULGULAR}

Hastaların ortalama yaşı ve ortalama takip süreleri sirası ile 70,2 (51-81) yll ve 9,2 (2-18) ay olarak tespit edildi. Hastaların 8 (\%80)'nin erkek, 2 (\%20)'nin kadın olduğu ve hepsinin ilk başvuru şikayetlerinin makroskopik hematüri olduğu görüldü. Hastaların demografik özellikleri ve histopatolojik bulguları Tablo 1'de sunulmuştur. 2 hasta hariç bütün hastalarda sigara içim öyküsü olduğu görüldü (\%80). Sigara içenlerde ortalama sigara miktarı 54 paket/yll (25-100 paket/yll) olarak hesaplandi. Hastaların hiçbirinde pelvik radyoterapi öyküsü veya siklofosfamid kullanımı yoktu. Başvuru esnasında mesane tümörü ön tanısı ile yapilan TUR-MT sonrası patolojik incelemede 3 (\%30) hastada evre pT1, 7 (\%70) hastada evre pT2 tümör tespit edildi ve hiçbir hastada eşlik eden karsinoma in situ (CIS) varlığ yoktu. Ortalama tümör boyutlarının 55,1 (6-100) mm olduğu tespit edildi. 4 (\%40) hastada sarkomatoid farklılaşma ile birlikte ürotelyal kanser görülürken hiçbir hastada diğer varyant histolojiler tespit edilmedi (Resim 1) (Tablo 2). pT1 patolojiye sahip hastalara re-TUR-MT yapıldı ve 1 (\%33) hastada evre pT2 tümör, 2 (\%66) hastada evre pT1 tümör görüldü. Evre pT1 patolojiye sahip olan ve erken radikal sistektomiyi kabul etmeyen iki hastaya da rekürrens ve progresyonu önlemek amacıyla intravezial BCG (Bacillus calmette guerin) tedavisi uyguland. Bu iki hastadan birinin kontrollerinde nüks gözlenmesi üzerine sisplatin bazlı kemoterapi (KT) verildi ve diğer hastanın takip süresince kontrollerinde nüks gözlenmedi. Evre pT2 tümöre sahip ve erken sistektomiyi kabul etmeyen iki hastadan birine komplet rezeksiyon ve pelvik radyoterapi uygulandı ve hastanın takiplerinde nüks tümör gözlenmedi. Diğer hastaya ise genel durum bozukluğu nedeniyle ek tedavi uygulanamadı ve hasta 6 aylık takibin sonunda exitus oldu. Altı (\%60) hastaya erken radikal sistektomi ve bilateral genişletilmiş lenfadenektomi ameliyatı uygulandı (Resim 2). Hastaların histopatolojik incelemelerinde $1(\% 16,6)$ hastada evre pT2b tümör, 3 (\%50) hastada evre pT3 tümör ve $2(\% 33,3)$ hastada evre pT4 tümörün olduğu görüldü. Üç (\%50) hastada lenf nodu metastazı $(\mathrm{N}+)$ olduğu görüldü ve üç (\%50) hastada eşlik eden CIS varlığı saptandı. Hastaların tamamında tümörler yüksek dereceli idi. Hastaların varyant histolojiye sahip olmaları nedeniyle ek immunohistokimyasal incelemeler yapildı (Tablo 2). Radikal sistektomi sonrasi $2(\% 33,3)$ hastaya adjuvan kemoterapi (KT) verildi ve bir hasta 11 aylık takip süresi sonrasında exitus oldu, diğer hasta ise 18 aylık takip sürecinde halen hayattadır. Ortalama 9,2 aylık takip süresinde tüm hastalar değerlendirildiğinde 4 (\%40) hastanın hayatta olduğu, 6 (\%60) hastanın ise hastalığa bağlı exitus olduğu görüldü. 
Tablo 2: Histopatolojik ve immunohistokimyasal sonuçlar

\begin{tabular}{|c|c|c|c|c|c|c|c|c|c|c|}
\hline Olgu & $\begin{array}{l}\text { Tümörün } \\
\text { Lokalizasyonu }\end{array}$ & $\begin{array}{l}\text { Primer } \\
\text { Evre }\end{array}$ & $\begin{array}{l}\text { Primer } \\
\text { Tümör } \\
\text { Grade }\end{array}$ & $\begin{array}{l}\text { Tümör Çap1 } \\
(\mathrm{mm})\end{array}$ & $\begin{array}{l}\text { Tümör } \\
\text { Nekrozu }\end{array}$ & Histolojik Tip & \begin{tabular}{|l|} 
Radikal \\
Sistektomi \\
Evre \\
\end{tabular} & \begin{tabular}{|l} 
Radikal \\
Sistektomi \\
Grade \\
\end{tabular} & $\begin{array}{l}\text { Lenf Nodu } \\
\text { Tutulumu }\end{array}$ & $\begin{array}{l}\text { İmmunohistokimyasal } \\
\text { pozitif değerler }\end{array}$ \\
\hline I & $\begin{array}{l}\text { Sol ve sağ yan } \\
\text { duvar }\end{array}$ & pT1 & Yüksek & 24 & Yok & $\begin{array}{l}\text { Sarkomatoid } \\
\text { karsinom }\end{array}$ & pT4a & Yüksek & N1 & $\begin{array}{l}\text { Pan-sitokeratin, } \\
\text { Vimentin, Cam5.2 }\end{array}$ \\
\hline II & $\begin{array}{l}\text { Sağ yan duvar } \\
\text { ve trigon }\end{array}$ & pT1 & Yüksek & 56 & Yok & $\begin{array}{l}\text { Sarkomatoid } \\
\text { karsinom }\end{array}$ & Yok & Yok & $\mathrm{Nx}$ & $\begin{array}{l}\text { Pan-sitokeratin, EMA, } \\
\text { Kİ-67 }\end{array}$ \\
\hline III & Yaygin & pT2b & Yüksek & 83 & Var & $\begin{array}{l}\text { Sarkomatoid } \\
\text { karsinom }\end{array}$ & pT4b & Yüksek & N1 & $\begin{array}{l}\text { Vimentin, Kİ-67, } \\
\text { CK7,CK20, HMWCK, } \\
\text { p63 }\end{array}$ \\
\hline IV & Sağ yan duvar & pT2b & Yüksek & 100 & Var & $\begin{array}{l}\text { Sarkomatoid } \\
\text { karsinom }\end{array}$ & Yok & Yok & $\mathrm{Nx}$ & $\begin{array}{l}\text { Pan-sitokeratin, CD8 T } \\
\text { lenfosit, GATA-3, p63 }\end{array}$ \\
\hline V & $\begin{array}{l}\text { Sol yan duvar } \\
\text { ve kubbe }\end{array}$ & pT2a & Yüksek & 74 & Var & $\begin{array}{l}\text { Sarkomatoid } \\
\text { karsinom }\end{array}$ & pT3a & Yüksek & No & $\begin{array}{l}\text { Pansitokeratin, Vimentin, } \\
\text { Kİ-67 }\end{array}$ \\
\hline VI & Kubbe & pT2b & Yüksek & 100 & Var & $\begin{array}{l}\text { Sarkomatoid } \\
\text { karsinom }\end{array}$ & pT3b & Yüksek & No & $\begin{array}{l}\text { Pansitokeratin, GATA- } \\
\text { 3, Vimentin, Cam5.2, } \\
\text { CK8/18 }\end{array}$ \\
\hline VII & Trigon & pT2a & Yüksek & 30 & Var & $\begin{array}{l}\text { Sarkomatoid } \\
\text { karsinom }\end{array}$ & pT2b & Yüksek & N1 & $\begin{array}{l}\text { MLH-1, MLH-2, MSH- } \\
\text { 6, PMS-2, p53, CD3 T } \\
\text { lenfosit, CD8 T lenfosit, } \\
\text { PDL-1 }\end{array}$ \\
\hline VIII & Sol yan duvar & pT2a & Yüksek & 43 & Var & $\begin{array}{l}\text { Sarkomatoid } \\
\text { karsinom }\end{array}$ & pT3b & Yüksek & No & $\begin{array}{l}\text { Pansitokeratin, Vimentin, } \\
\text { Cam5.2 }\end{array}$ \\
\hline IX & Sağ yan duvar & pT2b & Yüksek & 35 & Var & $\begin{array}{l}\text { Sarkomatoid } \\
\text { karsinom }\end{array}$ & Yok & Yok & $\mathrm{Nx}$ & Kİ-67, Desmin \\
\hline $\mathrm{X}$ & $\begin{array}{l}\text { Sol yan duvar } \\
\text { ve kubbe }\end{array}$ & pT1 & Yüksek & 6 & Var & $\begin{array}{l}\text { Sarkomatoid } \\
\text { karsinom }\end{array}$ & Yok & Yok & $\mathrm{Nx}$ & $\begin{array}{l}\text { GATA-3, CD44, p53, p63, } \\
\text { HMWCK, PDL-1 }\end{array}$ \\
\hline
\end{tabular}

\section{TARTIŞMA}

Son yillarda mesane kanseri tanisinda immünohistokimyasal yöntemlerin kullanımının artması varyant histolojilerin insidansının giderek yükselmesine neden olmaktadır. İlk olarak Robson tarafindan 1935 yılında tanımlanan sarkomatoid tümörlerin başlıca kadın genital sistemi olmak üzere her iki cinsiyette birçok organ ve sistemde varllğ 1 bildirilmiştir (7). Birçok organda karşımıza çıkmasından dolayı klinik gidişleri ve semptomları farklılık göstermektedir. Renal pelvis, üreter ve prostatik üretra dahil ürotelyumun farklı bölümlerinde rastlanılmaktadır (8). Dünya Sağlık Örgütünün (DSÖ) 2016 sınıflamasinda mesanenin sarkomatoid ürotelyal karsinomu olarak belirtilmektedir (9). MSK'nın semptomları ürotelyal kanserlerle benzerdir ve hastalar genellikle makroskopik hematüri, dizüri, noktüri, akut üriner retansiyon ve pelvik ağrı gibi şikayetlerle hekime başvurmaktadırlar (10). Çalışmamızdaki hastaların tamamının makroskopik hematüri şikayeti ile tarafimıza başvurduğunu görmekteyiz. Sarkomatoid karsinomların etiyolojisi ürotelyal tümörlerle ortak olsa da radyoterapi öyküsü ve siklofosfamid kullanımına dikkat çekilmektedir (11-13). Diğer etiyolojik faktörler arasında mesanenin ürotelyal kanserinde de gördüğümüz sigara kullanımı, tekrarlayan inflamatuvar durumlar, diyabetes mellitus ve mesane disfonksiyonu yer almaktadır (14). MSK epitelyal veya mezenkimal farklılaşmanın immunohistokimyasal veya morfolojik olarak gösterilmesi ile ürotelyal karsinomlardan ayrilmaktadır. Makroskopik olarak büyük, polipoid ve infiltratif karakterizasyon göstermektedir. Mikroskopik olarak saf iğsi, yuvarlak ve pleomorfik büyük hücreler görülür ve leiomyosarkom, kondrosarkom, rabdomyosarkom, liposarkom ve miksoid veya sklerozan alanlardan oluşmaktadır (12). Bazı çalışmalarda karsinosarkom ve sarkomatoid karsinom farklı varyant histolojiler olarak tanımlanmaktadırlar fakat molekü- 


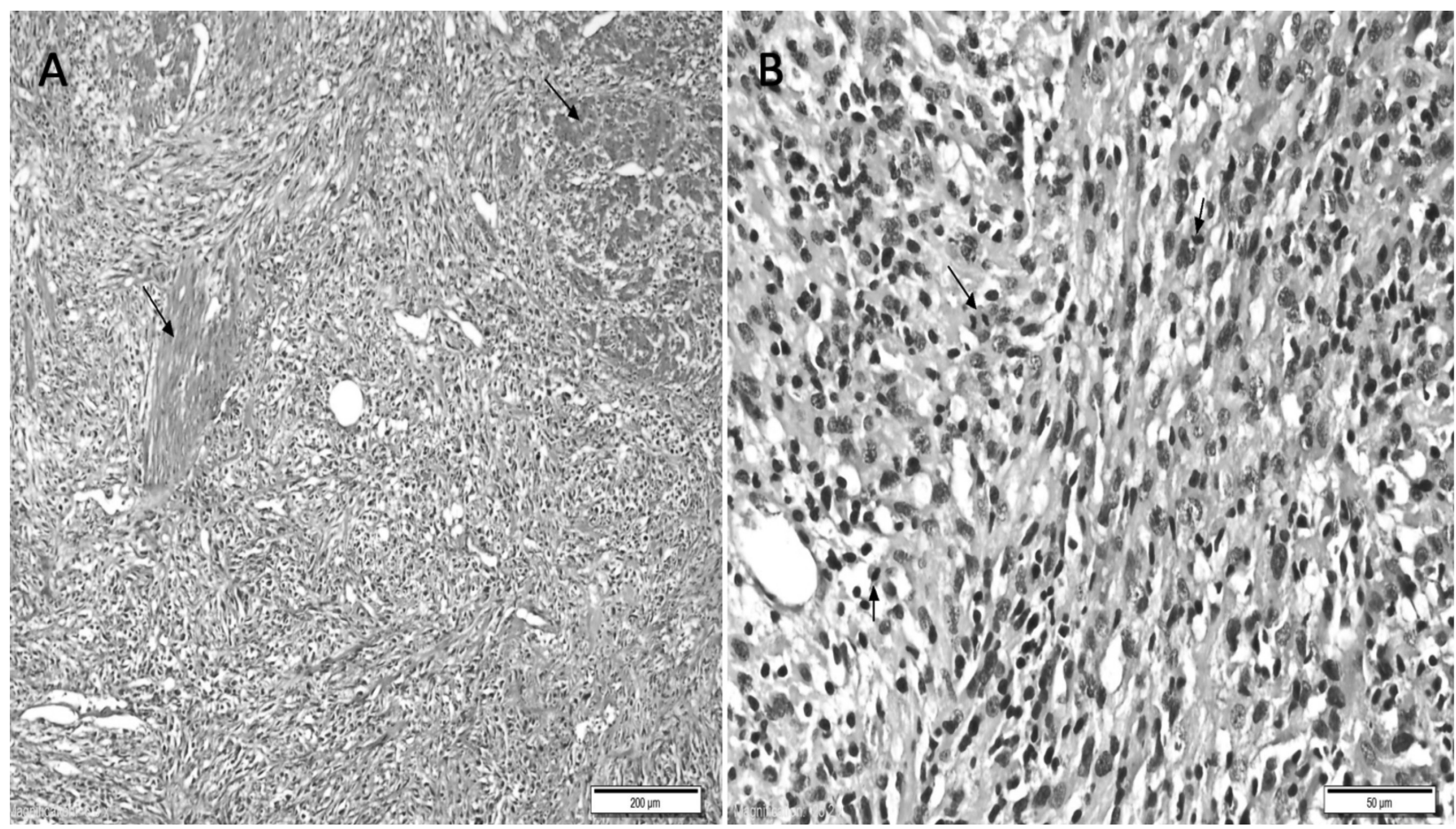

Resim 1: A- Ürotelyal karsinom içinde yer alan ve muskularis propria’yı infiltre eden sarkomatoid değişiklikler (ok: kas demeti) (H\&E, x200) B- Yüksek gradeli atipi ile birlikte olan iğsi hücreler (ok: Artmış mitoz) (H\&E, x400)

ler çalışmaların sonuçlarına göre sarkomatöz ve karsinomatöz yapılara farklılaşan monoklonal orjinlere sahiptirler $(8,15)$. Sarkomatoid karsinomun epitelyal ve mezenkimal komponentlerini oluşturan ve eş zamanlı eşlik edebilen tümörlerden ayrımını yapabilmek için ek immunohistokimyasal yöntemlere başvurulmaktadir. Epitelyal komponent EMA (epitelyal membran antijen), pan-sitokeratin ve vimentin ile pozitif boyanma sonucunda belirlenirken, mezenkimal komponent ise vimentin veya spesifik markerlardan keratin AE1/AE3, keratin CAM 5.2 ve EMA kullanılarak belirlenmektedir $(16,17)$. Fakat bazen EMA veya pan-sitokeratin gibi geleneksel epitelyal biyobelirteçler ile fokal boyanma olmakta bu da küçük biyopsi spesmenlerinde tanıyı zorlaştırmaktadır. Lewis ve ark yaptı̆̆ 1 çalışmada MSK'da en sık pan-sitokeratin (\%80), EMA (\%73) ve p63 (\%36) ile boyanmanın olduğu bildirilmektedir. Ayrıca EMA ve pan-sitokeratin ile negatif boyanan hastalarda bazen p63 ile pozitif boyanmanın olabildiği gösterilmiştir (18). Sarkomatoid karsinomlar sitokeratin immun reaktivitesine sahip olabilmelerinden dolayı histopatolojik tanıda benign natürlü nonepitel- yal bir tümör olan psödosarkomatöz miyofibroblastik proliferasyon/inflamatuar myofibroblastik tümör ile karışabilmektedirler. Miyofibroblastik tümörler miyofibrobilastik farklılaşma gösteren iğsi hücreler ve çeşitli inflamatuar hücreler içermektedirler. Genitoüriner sistem içinde en çok mesanede saptanan miyofibroblastik tümörlerin immunohistokimyasal olarak ayrımını yapabilmek için h-caldesmon, myogenin ve özellikle ALK-1 kullanılmaktadır (19).

MSK’nun genellikle hepsi kötü diferansiye ve andiferansiye özelliklere sahiptirler ve bu hastaların çoğu en azından kasa invaziv mesane kanseri veya T4 evre olarak başvurmaktadırlar. Ürotelyal kanser ile karşılaştırıldığında MSK'nun yüksek oranda ileri evre tümöre (pT3-T4 \%34 - \%28) ve daha fazla metastatik hastalığa $(\mathrm{N}+/ \mathrm{M}+>\% 20-\% 10)$ sahip olduğunu görmekteyiz (4). SEER (Surveillance Epidemiology and End Results) veritabanına bakıldığında MSK ile başvuran hastaların \%25'i lokal hastalığa, \%52'i bölgesel yayılmaya ve $\% 15$ 'i uzak metastaza sahiptirler (20). Bölgesel hastalığın veya uzak metastatik hastalığın olması ölüm riskini sırasıyla 2 ve 8 kat artırmaktadır. Sarkomatoid 


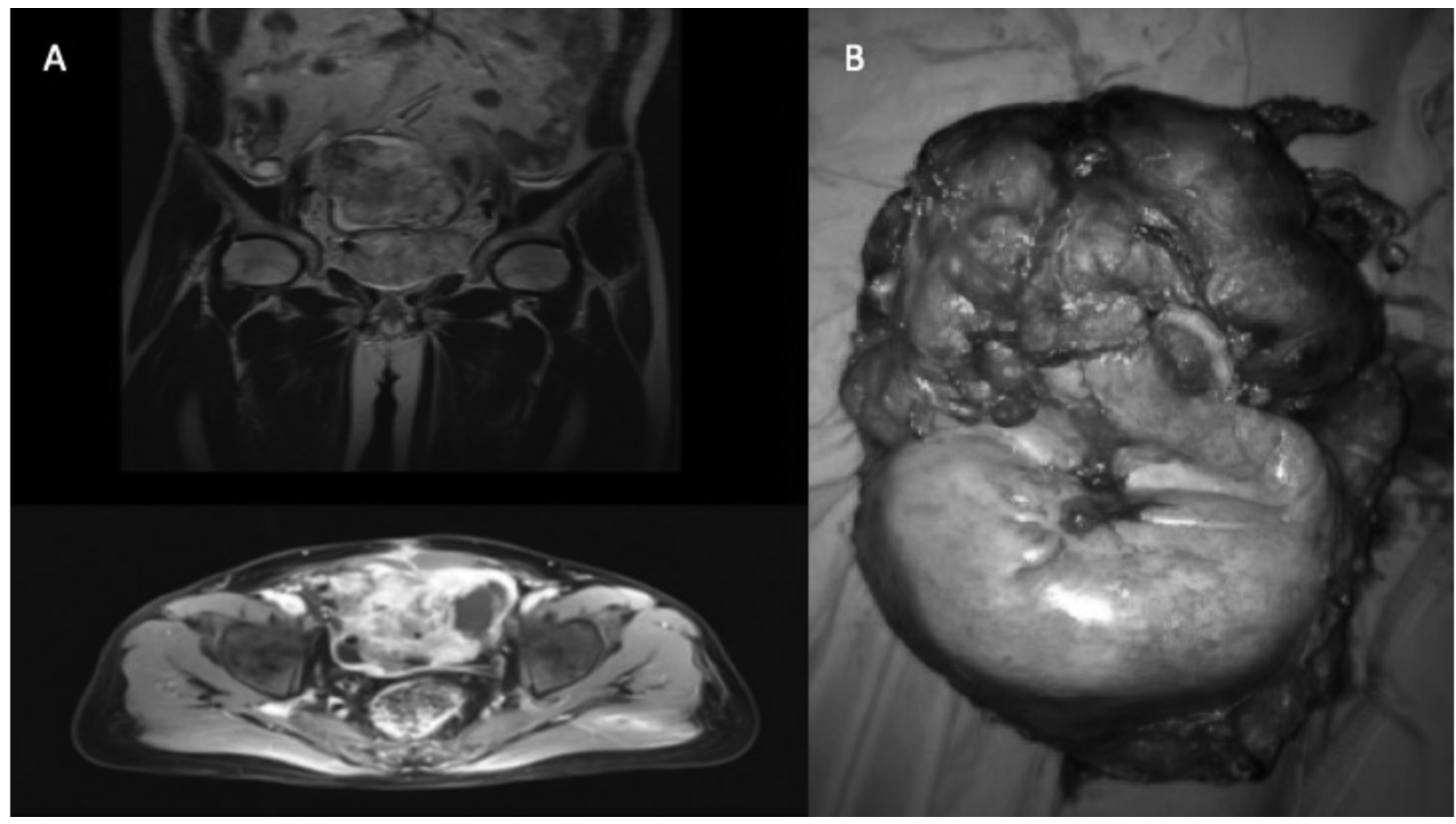

Resim 2: A- Mesanede ve rektus kası komşuluğundaki kitlenin tüm abdomen MRI görüntüsü

B- Sistektomi materyali

karsinomlarda ortalama sağkalımın 10-17 ay olduğu, lokal, bölgesel hastalık ve uzak metastaz olarak ayrı ayrı değerlendirildiğinde ortalama sağkalımların 21 ay, 10 ay ve 2 ay olduğu bildirilmektedir (8). Bizim hasta grubumuzda ortalama sağ kalım 9,2 aydır. Bu oranlar göz önünde bulundurulduğunda MSK'nun tedavisi konusunda literatürde randomize kontrollü çalışmaların bulunmaması nedeniyle tedavide TUR-MT veya mesane koruyucu diğer yöntemlerin aksine KT veya radyoterapinin (RT) de kullanıldığı daha ekstirpatif yöntemlere başvurulmaktadır. SEER veritabanına göre tedavide parsiyel sistektomi tercih edildiğinde iki yıllık sağkalımın \%14 olduğu fakat radikal sistektomi tercih edildiğinde bu oranın \%52'e yükseldiğini görmekteyiz (20). Sistektomi, KT ve RT’nin kullanıldığı multimodal tedavi yöntemleri ile çeşitli serilerde uzun sağkalım süreleri elde edilmiştir (21). Adjuvan KT ve RT sonrası literatürdeki çeşitli sağkalım oranları sırasıyla \% $15-40$ ve \%5-65 arasında değişmektedir (8). Bizim çalışmamızda da radikal sistektomi sonrası adjuvan KT verilen bir hasta 18 aylık takip süresinde halen hayattadır. MSK'da neoadjuvan KT’nin yerini değerlendirdiğimizde; RS öncesi neoadjuvan KT verildiğinde pT0 evreye \%45 hastada, neoadjuvan KT verilmediğinde TUR-M veya RS ile sadece \%12 hastada pT0 evre elde edilmektedir (4). Mevcut literatürde MSK üzerine uzun takip süreli, randomize kontrollü çalışmaların olmaması nedeniyle kesin tedavi seçeneği üzerinde fikir birliği yoktur. Vaka serimizdeki hastalara en kısa sürede radikal sistektomi uygulanmış olsa da hangi tedavi rejiminin hangi hastaya nasıl uygulanacağı hakkında bir fikir birliği henüz bulunmamakta ve hastalar hala kısa sağkalım sürelerine sahiptirler.

\section{SONUÇ}

Ürotelyumun varyant histolojili tümörü olan sarkomatoid karsinomların doğru olarak ayırt edilerek zamanında tanısı konulmalıdır. Klinikte immunohistokimyasal ve elektromikroskopik yöntemlerin rutin kullanımı ile varyant histolojiye sahip hastalara tanı daha net konulabilecektir. Ayrıca moleküler biyolojideki gelişmeler ve genetik metodolojinin artan kullanımı sayesinde gelecekte yeni tedavi stratejilerinin oluşması sağlanmalıdır. 


\section{KAYNAKLAR}

1. Ferlay J, Soerjomataram I, Ervik M, Dikshit R, Eser S, Mathers C. GLOBOCAN 2012 v1. 0, Cancer Incidence and Mortality Worldwide: IARC CancerBase No. 11 Internet. Lyon: IARC 2013.

2. Reisz PA, Laviana AA, Chang SS. Management of Highgrade T1 Urothelial Carcinoma. Curr Urol Rep 2018;19:103.

3. Müller-Hermelink HK, Engel P, Kuo T, et al. Pathology \& genetics, tumours of the lung, pleura, thymus and heart. World Health Organization Classification of Tumors Travis WD, Brambilla E, Müller-Hermelink HK, Harris CC, Eds IARC Press, Lyon 2004:146-47.

4. Klaile Y, Schlack K, Boegemann M, Steinestel J, Schrader AJ, Krabbe L-M. Variant histology in bladder cancer: how it should change the management in non-muscle invasive and muscle invasive disease? Transl Androl Urol 2016;5:692.

5. Wang J, Wang FW, LaGrange CA, Hemstreet III GP, Kessinger A. Clinical features of sarcomatoid carcinoma (carcinosarcoma) of the urinary bladder: analysis of 221 cases. Sarcoma 2010;2010.

6. Stamatiou K, Galariotis N, Michailidis I, Petrakopoulou N, Moustou H, Zizi-Sermpetzoglou A. Sarcomatoid carcinoma of the urinary bladder: a clinicopathological study of 4 cases and a review of the literature. Korean J Urol 2010;51:724-28.

7. Rabson SM. Atypical Carcinoma of the Urinary Bladder Simulating Myosarcoma: Report of Two Cases and Review of the Literature1. J Urol 1935;34:638-69.

8. Cheng L, Zhang S, Alexander R, , et al. Sarcomatoid carcinoma of the urinary bladder: the final common pathway of urothelial carcinoma dedifferentiation. Am J Surg Pathol 2011;35:e34-e46.

9. Humphrey PA, Moch H, Cubilla AL, Ulbright TM, Reuter VE. The 2016 WHO Classification of Tumours of the Urinary System and Male Genital Organs-Part B: Prostate and Bladder Tumours. Eur Urol 2016;70:106-19.

10. Baseskioglu B, Duman BB, Kara IO, Can C, Yildirim M, Acikalin M. Early detection and gemcitabine/cisplatin combination positively effect survival in sarcomatoid carcinoma of the urinary bladder. Asian Pac J Cancer Prev 2012;13:5729-33.

11. Erdemir F, Uluocak N, Tunç M, Öcan F, Gökçe Ö, Kılıçaslan I. Mesanenin sarkomatoid kanseri. Turk J Urol 2006;32:46266.

12. Moschini M, D’andrea D, Korn S, Irmak Y, Soria F, Compérat E, et al. Characteristics and clinical significance of histological variants of bladder cancer. Nat Rev Urol 2017;14:651.

13. Mukhopadhyay S, Shrimpton AE, Jones LA, Nsouli IS, Abraham Jr NZ. Carcinosarcoma of the urinary bladder following cyclophosphamide therapy: evidence for monoclonal origin and chromosome 9p allelic loss. Arch Pathol Lab Med 2004;128:e8-e11.

14. Young RH, Eble JN. Unusual forms of carcinoma of the urinary bladder. Human pathology 1991;22:948-65.

15. Gronau S, Menz CK, Melzner I, Hautmann R, Möller P, Barth TF. Immunohistomorphologic and molecular cytogenetic analysis of a carcinosarcoma of the urinary bladder. Virchows Arch 2002;440:436-40.

16. Sanchez JEH, Figueira YR, Gonzalez RT, Lopez RM, Tejeda LMG. Sarcomatoid carcinoma of the urinary bladder: a case report and review of the literature. J Med Cases 2014;5:11619.

17. Choi H-R, Sturgis EM, Rosenthal DI, Luna MA, Batsakis JG, El-Naggar AK. Sarcomatoid carcinoma of the head and neck: molecular evidence for evolution and progression from conventional squamous cell carcinomas. Am J Surg Pathol 2003;27:1216-20.

18. Lewis Jr JS, Ritter JH, El-Mofty S. Alternative epithelial markers in sarcomatoid carcinomas of the head and neck, lung, and bladder-p63, MOC-31, and TTF-1. Mod Pathol 2005; $18: 1471$.

19. Lekas A, Parasi A, Papathomas TG, et al. Pseudosarcomatous myofibroblastic lesion of the urinary bladder: A rare entity posing a diagnostic challenge and therapeutic dilemma. Diagn Pathol 2008;3:11.

20. Malla M, Wang JF, Trepeta R, Feng A, Wang J. Sarcomatoid carcinoma of the urinary bladder. Clin Genitourin Cancer 2016;14:366-72.

21. Lopez-Beltran A, Pacelli A, Rothenberg H, et al. Carcinosarcoma and sarcomatoid carcinoma of the bladder: clinicopathological study of 41 cases. J Urol 1998;159:1497-503. 